\title{
PROTEIN METABOLISM OF THE RAT UTERUS DURING THE OESTROUS CYCLE, PREGNANCY AND PSEUDO- PREGNANCY, AND AS AFFECTED BY AN ANTI- IMPLANTATION COMPOUND, ICI 46,474
}

\author{
R. J. REID AND P. J. HEALD \\ Department of Biochemistry, University of Strathclyde, Glasgowe, C.1
}

(Received 28th October 1970)

\begin{abstract}
Summary. The uptake of $\left[{ }^{3} \mathrm{H}\right]$ leucine into total uterine protein of the 5-day cycling rat has been examined during the oestrous cycle, early pregnancy and pseudopregnancy and in animals receiving an antiimplantation compound, ICI 46,474.

It has been shown that uptake in the oestrous cycle is maximal at dioestrus and minimal at oestrus, an event which is out of phase with the known times of maximal oestrogen release. In the pseudopregnant rat, maximal protein synthesis occurred on Days 3 and 4 , the uptake on Days 5 to 8 being the same lowered values as on Day 1. Consideration of this result in relation to changes in the oestrous cycle leads to the conclusion that the stimulated uptake is not due to oestrogen acting alone. In the pregnant rat, protein synthesis is markedly stimulated by the morning of Day 5 (10.00 hours). Comparing this with results in the pseudopregnant rat, it is concluded that the increased protein synthesis is indicative of the commencement of early decidualization which, by this measure, is well advanced at the time of experimentation. It has further been shown that an implantation-inhibiting dose of ICI 46,474 results in a pattern of protein synthesis similar to that found in pseudopregnancy. Examination of this, together with previous data, suggests that ICI 46,474 may suppress the protein synthesis which normally occurs on Day 5 of pregnancy.
\end{abstract}

\section{INTRODUCTION}

During investigations of biochemical mechanisms underlying egg implantation in the rat it was found that there are marked alterations in the protein metabolism of rat uterine tissue during the preimplantation stages of pregnancy (Reid \& Heald, 1970). The rate of uptake of $\left[{ }^{3} \mathrm{H}\right]$ leucine into uterine proteins increased markedly between Days 2 and 3 of pregnancy and continued to rise until Day 5. It has also been shown that nucleic acid metabolism is stimulated by Day 3 of pregnancy (Heald \& O'Grady, 1970) and that this is accompanied by a simultaneous increase in the activity of the hexose monophosphate shunt in the intact tissue (Surani \& Heald, 1971).

The precise significance of these early biochemical changes is somewhat 
obscure. In the rat, fertilized eggs enter the uterus late on the 4th day of pregnancy (Psychoyos, 1967) and implantation usually begins $24 \mathrm{hr}$ later in the evening of Day 5. It is, therefore, possible that the patterns of nucleic acid and protein synthesis observed during the first 5 days of pregnancy are associated with the preparation of the uterine wall for blastocyst attachment and implantation (see Heald \& O'Grady, 1970; Reid \& Heald, 1970).

To examine this concept further, three additional studies have been made. First, the incorporation of $\left[{ }^{3} \mathrm{H}\right]$ leucine into uterine protein was examined during the oestrous cycle since it has been suggested (Finn \& Martin, 1970) that changes in the histology of the uterus during the first few days of pregnancy are due to a combination of hormonal responses generated during the oestrous cycle.

Secondly, pseudopregnancy was chosen since it is well established that the pseudopregnant uterus is under a hormonal regimen similar to that of normal pregnancy (Mayer, 1963) and is also able to permit the implantation of blastocysts transferred to it from a donor animal at the appropriate time (Psychoyos, 1967).

Thirdly, the effects of an anti-implantation compound, IGI 46,474 (trans1-( $p$ - $\beta$-dimethylaminoethoxyphenyl)-1,2 diphenyl but-1-ene), was examined. This compound has been shown to be antioestrogenic in rats (Harper \& Walpole, 1967a) and, in doses preventing implantation, to abolish the normal pattern of RNA synthesis during Days 3 to 5 of pregnancy (O'Grady, Heald \& O'Hare, 1970). It was, therefore, of interest to see whether protein synthesis was affected following similar treatment.

\section{MATERIALS AND METHODS}

Rats

The rats were adult, virgin females of a Holtzman-derived Sprague Dawley strain weighing between 220 and $260 \mathrm{~g}$. They were kept in windowless rooms with a 14-hr photoperiod ( 06.00 hours to 20.00 hours) and a mean temperature of $22^{\circ} \mathrm{C}$. Food (Oxoid Breeders Diet) and water were freely provided. The rats were mated and the morning on which spermatozoa were found in the vaginal smear was called Day I of pregnancy. Pseudopregnancy was induced by caging the females singly with vasectomized males and the day on which a copulation plug was found on the floor of the cage or in the vagina was designated Day 1 of pseudopregnancy. Vaginal smears of animals used in the oestrous cycle experiments were taken daily and each animal had undergone at least two clearly defined cycles before use.

\section{Administration of $I C I 46,474$}

Mated rats were divided into three groups, each containing sixteen rats, and were dosed orally between 09.30 and 09.45 hours on Day 2 of pregnancy as follows:

Group 1 (controls) received $0.5 \%$ (w/v aqueous) Tween 80 .

Group 2 received ICI 46,474 at a dose of $0.2 \mathrm{mg} / \mathrm{kg}$ body weight.

Group 3 received IGI 46,474 at a dose of $0.05 \mathrm{mg} / \mathrm{kg}$ body weight. 
(ICI 46,474 was made up in aqueous $0.5 \%$ Tween 80 as described by Harper \& Walpole, 1967a).

\section{Uptake of $\left[{ }^{3} \mathrm{H}\right]$ leucine}

Rats were injected intravenously, under light ether anaesthesia, with $25 \mu \mathrm{Ci}$ $\left[{ }^{3} \mathrm{H}\right]$ leucine $[4,5-\mathrm{T}]$ (specific activity $23.5 \mathrm{Ci} / \mathrm{mmol}$ in $0.2 \mathrm{ml}$ of $0.9 \% \mathrm{w} / \mathrm{v}$ $\mathrm{NaCl}$; all injections were performed between 09.00 hours and 11.30 hours on any one day. The animals were killed (by decapitation) $30 \mathrm{~min}$ after injection and a sample of blood collected in a beaker containing about $50 \mathrm{mg}$ trisodium citrate; the blood was centrifuged to obtain a sample of plasma. The uterus was rapidly excised, trimmed free from fat and mesentery and lightly blotted on a filter paper pad which had been moistened with $0.9 \% \mathrm{w} / \mathrm{v} \mathrm{NaCl}$. Segments of uterine tissue from each horn were pooled and samples taken for dry weight determination (as described by Heald, O'Grady \& Howie, 1970). The remaining tissue was homogenized in ice-cold distilled water containing $50 \mu \mathrm{g} / \mathrm{ml}$ carrier leucine.

Protein was precipitated by the addition of an equal volume of $0.6 \mathrm{~N}-\mathrm{PCA}$ to aliquots of the homogenate. After standing in ice for 10 to $15 \mathrm{~min}$, the precipitate was centrifuged, washed twice with $0.3 \mathrm{~N}-\mathrm{PCA}$, once with ethanol, once with chloroform/methanol $(2: 1, \mathrm{v} / \mathrm{v})$, again with ethanol and finally with diethyl ether. The combined PCA washes were retained for the determination of acidsoluble radioactivity.

Protein samples were solubilized by incubation in $0.4 \mathrm{ml}$ hyamine hydroxide (hydroxide of hyamine 10X; Packard Instrument Co., La Grange, Ill., U.S.A.) at $37^{\circ} \mathrm{C}$ for $48 \mathrm{hr}$. Plasma samples $(0.1 \mathrm{ml})$, acid supernatant aliquots $(0.2 \mathrm{ml})$, and the solubilized protein solutions were each made up to $3.0 \mathrm{ml}$ with toluene and added to $12 \mathrm{ml}$ butyl PBD [5-(4-biphenyl)-2-(4-tert-butylphenyl)-1-oxa3,4-diazole] (British Drug Houses, Poole, Dorset) scintillator solution. Samples were counted in a Packard Series 4000 spectrometer using the Automatic External Standard to determine quench correction. Protein nitrogen was estimated in protein precipitated from $2 \cdot 0-\mathrm{ml}$ aliquots of homogenate by a micro-Kjeldahl technique (Bailey, 1967).

Statistical procedures were those described by Snedecor \& Cochrane (1967).

It has been shown (Reid, in preparation) that the uptake of $\left[{ }^{3} \mathrm{H}\right]$ leucine into uterine proteins follows an identical pattern in both the myometrium and endometrium and, for this reason, no attempt was made to differentiate between them in this investigation.

\section{RESULTS}

\section{Oestrous cycle}

No significant variation in the protein content of the uterine tissue occurred during the oestrous cycle (Table 1), a finding in agreement with previous results of Heald et al. (1970). Although the dry matter content of the tissue was lowest at pro-oestrus and oestrus, analysis of variance failed to show a significant deviation during the cycle (Table 1). However, when the incorporation of 
TABLE 1

PROTEIN NITROGEN, DRY MATTER CONTENT AND AGID-SOLUBLE RADIOACTIVITY OF RAT UTERUS DURING AN OESTROUS GYGLE

\begin{tabular}{l|c|c|c|c}
\hline Day of cycle & $\begin{array}{c}\text { No. of } \\
\text { rats }\end{array}$ & $\begin{array}{c}\text { Dry wt } \\
(\% \text { wet wt })\end{array}$ & $\begin{array}{c}\text { Protein nitrogen } \\
(\% \text { dry wt) }\end{array}$ & $\begin{array}{c}\text { Acid-soluble radioactivity } \\
(\text { counts/min/10 mg wet wt })\end{array}$ \\
\cline { 2 - 3 } Oestrus & 4 & $17 \cdot 08 \pm 0 \cdot 19$ & $10 \cdot 94 \pm 0.98$ & $672 \pm 226$ \\
Metoestrus & 4 & $18 \cdot 40 \pm 0 \cdot 40$ & $10 \cdot 82 \pm 0 \cdot 70$ & $507 \pm 187$ \\
Dioestrus 1 & 4 & $18 \cdot 29 \pm 0 \cdot 22$ & $11 \cdot 58 \pm 1 \cdot 38$ & $259 \pm 52$ \\
Dioestrus 2 & 4 & $17 \cdot 55 \pm 0 \cdot 51$ & $9 \cdot 84 \pm 0.19$ & $402 \pm 133$ \\
Pro-oestrus & 4 & $17 \cdot 14 \pm 0 \cdot 19$ & $9 \cdot 09 \pm 0 \cdot 87$ & $373 \pm 74$ \\
\hline
\end{tabular}

Values are expressed as means \pm S.E.

Analysis of variance showed no significant variation within each parameter measured.

radioactive leucine into the uterine protein was determined, a highly significant $(P<0.002)$ increase in the rate of incorporation occurred during the period of metoestrus and dioestrus (Text-fig. 1). The incorporation remained high on the 2nd day of dioestrus (Dioestrus 2), and decreased markedly by pro-oestrus. The data in Text-fig. 1 (and subsequent text-figures) are corrected to a standard count in the acid soluble fraction to minimize errors arising from possible fluctuations of the tissue pool of $\left[{ }^{3} \mathrm{H}\right]$ leucine. Such errors are likely to be small

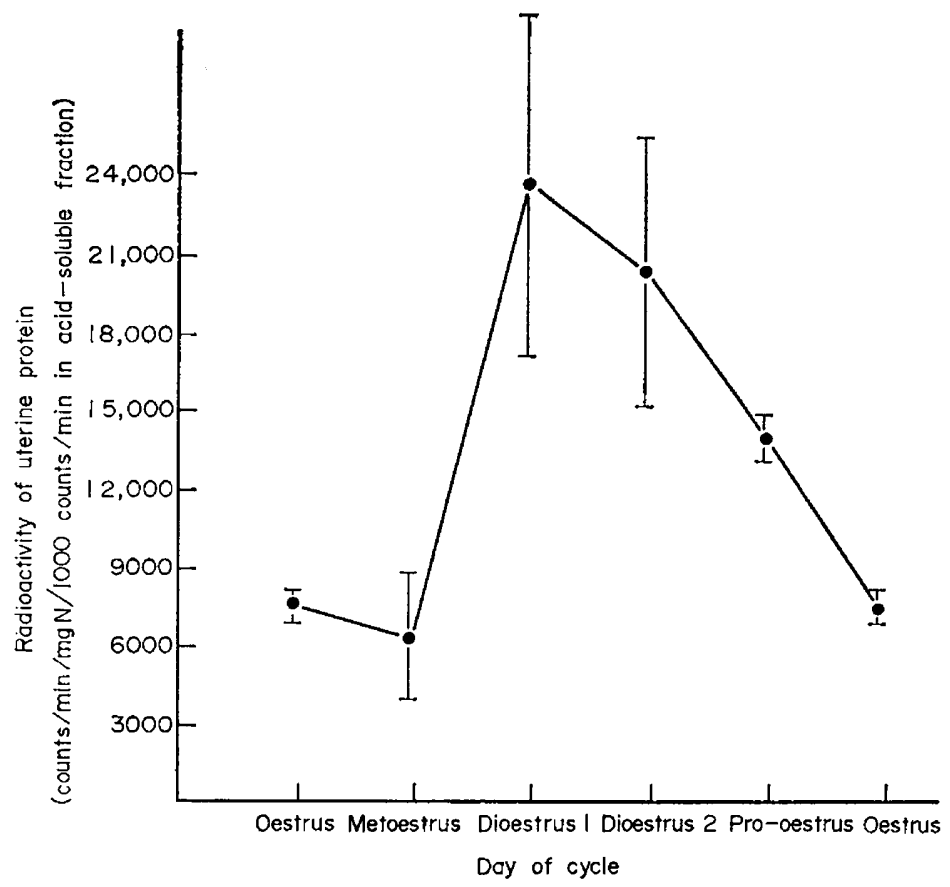

TEXT-FIG. 1. Radioactivity of total uterine protein of the rat following injection of $\left[{ }^{3} \mathrm{H}\right]$ leucine at different stages of the oestrous cycle. Animals were injected and analyses performed as described in the Materials and Methods section. All values are given as the mean (the horizontal lines represent the limit of the standard error) and are corrected to a standard count in the acid-soluble fraction. Each point represents results from four individual rats. 
since no significant variation was noted in the radioactivity of the acid soluble fraction (Table 1).

\section{Pseudopregnancy}

No significant changes occurred in the total nitrogen content/unit dry wt (Table 2) during the first 8 days of pseudopregnancy, nor in the dry matter content. Thereafter, levels remained low until Day 6 when a return of the dry matter content to the level found on Day 1 occurred (Table 2). The total radioactivity of the acid soluble fraction decreased between Days 1 and 2 and increased by Day 3 (Table 2). Thereafter, though fluctuating, the degree of scatter made the differences statistically non-significant.

In contrast, the incorporation of $\left[{ }^{3} \mathrm{H}\right]$ leucine into the uterine protein (Textfig. 2) showed a large increase on Days 3 and 4 of pseudopregnancy, falling to the original levels on Day 5 and remaining low for the further 3 days of the experimental period.

TABLE 2

PROTEIN NITROGEN, DRY MATTER CONTENT AND ACID SOLUBLE RADIOACTIVITY OF RAT UTERUS DURING EARLY PSEUDOPREGNANCY

\begin{tabular}{|c|c|c|c|c|}
\hline $\begin{array}{c}\text { Day of } \\
\text { pseudopregnancy }\end{array}$ & $\begin{array}{l}\text { No. of } \\
\text { rats }\end{array}$ & $\begin{array}{c}\text { Dry wt } \\
(\% \text { wet } w t)\end{array}$ & $\begin{array}{l}\text { Protein nitrogen } \\
(\% \text { dry matter })\end{array}$ & $\begin{array}{l}\text { Acid-soluble radioactivity } \\
\text { (counts/min/10 mg wet wt) }\end{array}$ \\
\hline $\begin{array}{l}1 \\
2 \\
3 \\
4 \\
5 \\
6 \\
7 \\
8\end{array}$ & $\begin{array}{l}4 \\
4 \\
4 \\
4 \\
4 \\
4 \\
4 \\
4\end{array}$ & $\begin{array}{l}19 \cdot 15 \pm 0 \cdot 33 \\
18 \cdot 65 \pm 0 \cdot 44 \\
17.51 \pm 0 \cdot 15 \\
17 \cdot 55 \pm 0 \cdot 32 \\
17 \cdot 28 \pm 0 \cdot 25 \\
18 \cdot 49 \pm 0 \cdot 65 \\
18 \cdot 60 \pm 3 \cdot 64 \\
19 \cdot 41 \pm 0 \cdot 29\end{array}$ & $\begin{array}{r}10.36 \pm 0.70 \\
10.82 \pm 0.48 \\
9.93 \pm 0.43 \\
9.68 \pm 0.29 \\
10.89 \pm 0.34 \\
8.80 \pm 0.77 \\
9.94 \pm 0.74 \\
9.66 \pm 0.77\end{array}$ & $\begin{array}{l}576 \pm 92 \\
286 \pm 31 \\
431 \pm 59 \\
345 \pm 73 \\
437 \pm 36 \\
519 \pm 85 \\
488 \pm 81 \\
363 \pm 23\end{array}$ \\
\hline
\end{tabular}

Values are expressed as means \pm S.E.

Analysis of variance showed no significant difference within each parameter measured.

Rats were mated with vasectomized males, injected with $\left[{ }^{3} \mathrm{H}\right]$ leucine and the uterus removed and analysed as described in the Materials and Methods section.

\section{Effects of ICI 46,474}

Previous work with the strain of rat used in these studies had shown that ICI 46,474 , at a dose level of $0.1 \mathrm{mg} / \mathrm{kg}$ body wt, given on Day 2 of pregnancy, completely abolished implantation, whereas a dose of $0.05 \mathrm{mg} / \mathrm{kg}$ given on the same day allowed normal pregnancy to ensue (O'Grady et al., 1970). In the present series, it was found (Text-fig. 3) that while $0 \cdot 1 \mathrm{mg} / \mathrm{kg}$ given orally on Day 2 reduced the size of the implantation sites measured on Day 9, a dose of $0.2 \mathrm{mg} / \mathrm{kg}$ was required to inhibit implantation completely. The two doses chosen were, therefore, $0.05 \mathrm{mg} / \mathrm{kg}$, and $0.20 \mathrm{mg} / \mathrm{kg}$, respectively.

In the control group and the groups receiving 46,474, the total protein nitrogen/unit dry matter reached a peak on Day 4 and decreased by Day 5 (Table 3). Parallel with this, the radioactivity of the acid-soluble pool decreased significantly by Day 5 in both the control group and the group receiving 0.05 $\mathrm{mg} / \mathrm{kg}$ of 46,474 , but no significant change was observed in the group receiving 


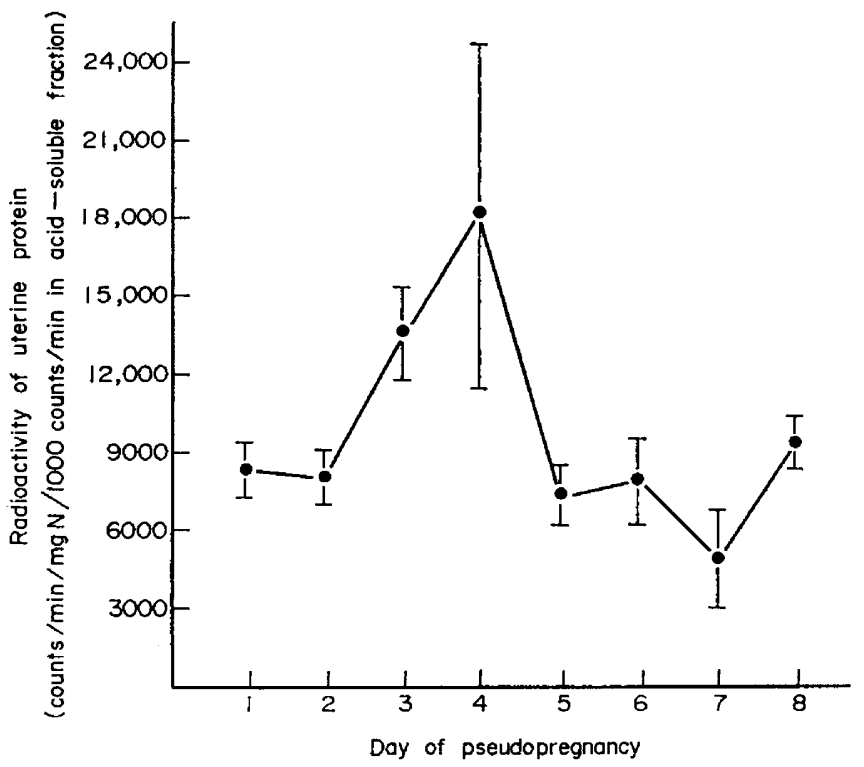

TEXT-FIG. 2. Radioactivity of uterine protein following the injection of $\left[{ }^{3} \mathrm{H}\right]$ leucine to the pseudopregnant rat. The experimental method and basis of calculation are as described for Text-fig. 1. Each point represents the mean \pm S.E. for four animals.

$0.2 \mathrm{mg} / \mathrm{kg}$. The dry matter content of all groups remained constant throughout (Table 3).

The incorporation of leucine into uterine protein is presented in Text-fig. 4. It will be noted that, whereas the uptake on Day 3 was elevated in all three groups, there was a decrease on Day 4, the decrease being greatest in the $0.20 \mathrm{mg} / \mathrm{kg}$

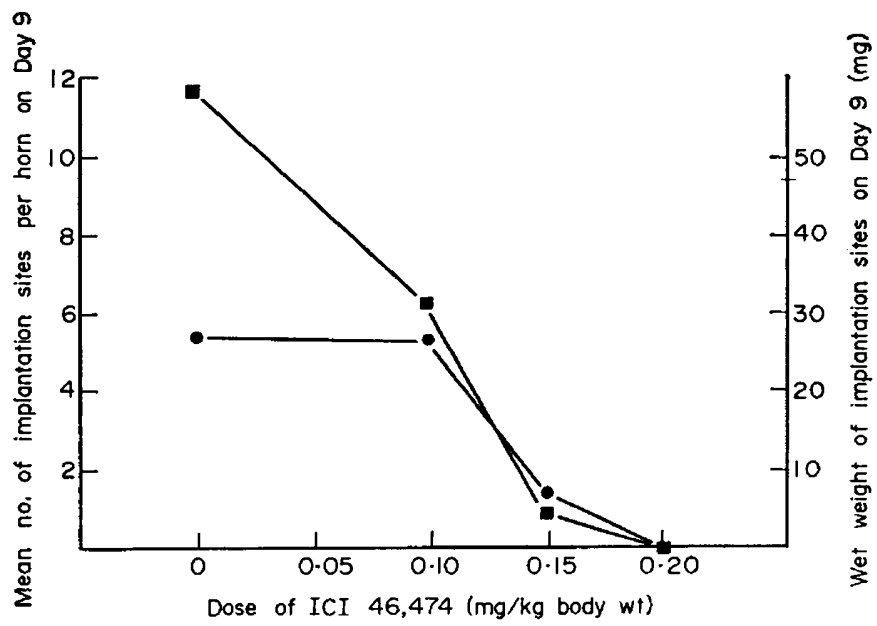

TexT-FIG. 3. The effect of ICI 46,474 upon the mean number per horn (O) and wet weight ( $\boldsymbol{D}$ ) of implantation sites found on Day 9 of pregnancy in the rat. Animals were mated and ICI 46,474 or vehicle alone was given as a single oral dose on Day 2 at 10.00 hours. Animals were killed on Day 9 at 10.00 hours and the mean weight and number of implantation sites were determined. Each point represents the mean $\pm S$.E. of determinations involving four rats. 
TABLE 3

EFFECT OF ICI 46,474 ON DRY MATTER, PROTEIN NITROGEN CONTENT AND ACID-SOLUBLE RADIOACTIVITY OF PREGNANT RAT UTERUS

\begin{tabular}{|c|c|c|c|c|}
\hline $\begin{array}{c}\text { Day of } \\
\text { pregnancy }\end{array}$ & $\begin{array}{l}\text { Dose of } 46,474 \\
(m g / k g \text { body } w t)\end{array}$ & $\begin{array}{l}\text { Dry wt } \\
(\% \text { wet wt })\end{array}$ & $\begin{array}{l}\text { Protein nitrogen } \\
(\% \text { dry wt })\end{array}$ & $\begin{array}{l}\text { Acid-soluble radioactivity } \\
\text { (counts/min } / 10 \mathrm{mg} \text { wet } w t)\end{array}$ \\
\hline $\begin{array}{l}2 \\
3 \\
4 \\
5\end{array}$ & Controls & $\begin{array}{l}18.97 \pm 0 \cdot 20 \\
17 \cdot 56 \pm 0 \cdot 16 \\
18 \cdot 04 \pm 0 \cdot 12 \\
16 \cdot 86 \pm 0 \cdot 81\end{array}$ & $\begin{array}{r}9.83 \pm 0.39 \\
10 \cdot 47 \pm 0 \cdot 46 \\
11 \cdot 12 \pm 0 \cdot 46 \\
9.51 \pm 0.54\end{array}$ & $\left.\begin{array}{l}555 \pm 22 \\
442 \pm 45 \\
491 \pm 22 \\
245 \pm 36\end{array}\right\} \quad P<0.01$ \\
\hline $\begin{array}{l}2 \\
3 \\
4 \\
5\end{array}$ & 0.05 & $\begin{array}{l}18 \cdot 19 \pm 0 \cdot 25 \\
18 \cdot 68 \pm 0 \cdot 25 \\
17 \cdot 53 \pm 0 \cdot 11 \\
17 \cdot 65 \pm 0 \cdot 63\end{array}$ & $\begin{array}{r}10.01 \pm 0.50 \\
9 \cdot 18 \pm 0.99 \\
10 \cdot 65 \pm 0.54 \\
9.69 \pm 0.38\end{array}$ & 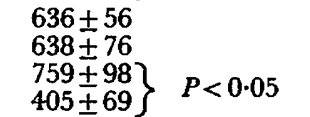 \\
\hline $\begin{array}{l}2 \\
3 \\
4 \\
5\end{array}$ & 0.20 & $\begin{array}{l}18.93 \pm 0 \cdot 20 \\
18 \cdot 08 \pm 0 \cdot 42 \\
18 \cdot 83 \pm 0 \cdot 54 \\
19 \cdot 03 \pm 0 \cdot 26\end{array}$ & $\left.\begin{array}{c}9.30 \pm 0.37 \\
9.73 \pm 0.38 \\
11.92 \pm 0.35 \\
10.45 \pm 0.21\end{array}\right\}\left\{\begin{array}{l}P<0.01 \\
P<0.02\end{array}\right.$ & $\begin{array}{l}532 \pm 49 \\
432 \pm 89 \\
430 \pm 31 \\
542 \pm 41\end{array}$ \\
\hline
\end{tabular}

Significant differences are indicated at the appropriate points. All other differences were not significant.

Animals were mated, dosed with ICI 46,474, injected with $\left[{ }^{3} \mathrm{H}\right]$ leucine and the uterine tissue removed and analysed as described in the Materials and Methods section. Values are expressed as means \pm S.E. Each group consisted of four animals.

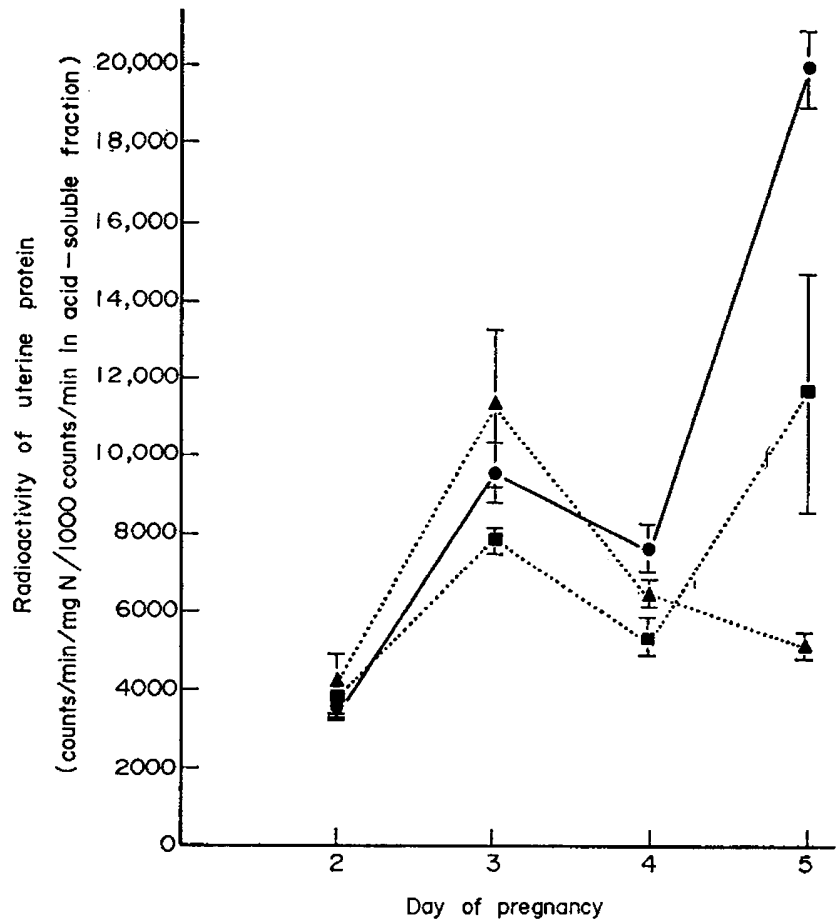

TEXT-FIG. 4. Effect of ICI 46,474 on the radioactivity of uterine protein following the injection of $\left[{ }^{3} \mathrm{H}\right]$ leucine to the pregnant rat. Animals were mated and dosed with ICI 46,474 as described for Text-fig. 3. The experimental method and basis of calculation are as described for Text-fig. 1. Each point represents the mean \pm S.E. of determinations involving four rats. 0 , Tween (control); $0,0.05 \mathrm{mg} / \mathrm{kg}$ ICI 46,$474 ; \Delta, 0.2 \mathrm{mg} / \mathrm{kg}$ ICI 46,474 . 
groups and least in the control group where the difference between Day 3 and Day 4 was statistically not significant. On Day 5 , both the control group and the group receiving $0.05 \mathrm{mg} / \mathrm{kg}$ had a markedly increased incorporation of leucine while that of the group receiving $0.20 \mathrm{mg} / \mathrm{kg}$ remained very low.

\section{DISGUSSION}

Comparison of the results obtained with the pseudopregnant and pregnant animals in this and a previous study (Reid \& Heald, 1970) shows a major difference in the protein synthesis activity of the uterus early on Day 5 of pregnancy. Thus, the increased incorporation into protein is found in both groups on Days 3 and 4 but only in the pregnant animal is protein synthesis very high on Day 5. In the pseudopregnant group, synthesis was low.

Although histological examination was not made with these rats, it is well established that implantation in the rat commences early on Day 5 with the appearance of the primary decidual reaction in the antimesometrial cells of the lumen and that the blastocysts show some attachment to the antimesometrial surface 107 to $109 \mathrm{hr}$ after ovulation (Krehbiel, 1937; Christie, 1966; DeFeo, 1967; Psychoyos, 1967). This timing places the first visible attachment at 12.00 to 14.00 hours on Day 5. Since the experiments in the present study were conducted by 10.00 hours on any one day, the greatly increased protein synthesis on the morning of Day 5 is considered to be a direct result of the initiation of the primary decidual reaction which by this measure is already strongly active. Further, since the pseudopregnant uterus of Day 5 is at its maximum point of sensitivity to stimuli (DeFeo, 1967; Psychoyos, 1967), it follows that the increased synthesis of protein found on Day 5 in the pregnant rat is a consequence and not a cause of decidualization. The lowered protein synthesis on Day 5 in the pseudopregnant rat contrasts with studies of RNA synthesis (O'Grady et al., 1970) when RNA metabolism was high on Day 5 of pseudopregnancy but decreased sharply on Day 6.

The results with ICI 46,474 show that an implantation-inhibiting dose given on Day 2 of pregnancy results in a low rate of protein synthesis on Day 5, compared with the rates in control animals and animals receiving an ineffective dose. The compound ICI 46,474 possesses antioestrogenic properties in the rat and has been considered to act, when doses are given on Day 2, by premature expulsion of the tubal ova (Harper \& Walpole, 1967b). Such an action would presumably result in the subsequent uterine function being similar to that of the pseudopregnant uterus and, thus, the decreased protein synthesis on Day 5 is explicable in such terms. However, separate studies of RNA synthesis following an anti-implantation dose of 46,474 on Day 2 of pregnancy (O'Grady et al., 1970) has shown that RNA synthesis is markedly increased on Day 5 to a level in excess of that found in normal pregnancy. Thus, uterine metabolism itself is directly affected by the compound and the results shown in Text-fig. 4 could equally imply that an inhibiting dose of 46,474 was exerting at least part of its action by suppressing mechanisms of protein synthesis at a time at which they are required for decidualization to begin.

Comparison of Text-figs. 1 and 2 suggests that factors stimulating protein 
synthesis in the uterus may be similar in early pregnancy and pseudopregnancy and during the oestrous cycle. Thus, following the day of oestrus, equivalent to Day 1 of pregnancy, protein synthesis remained low for 1 day (metoestrus) and increased on the 2 days of dioestrus, falling to lower rates during pro-oestrus. Since the animals have a 5-day cycle, the timing of these experiments corresponds to Days 1 to 5 of pseudopregnancy. Although stimulation of protein synthesis in uterine tissue by oestrogen is well established, it is less clear how much the increased protein synthesis in the above experiment can be attributed to this cause. Yoshinaga, Hawkins \& Stocker (1969) found that the ovarian oestrogen secretion rate in the rat was extremely low, as was the plasma oestrogen concentration, during oestrus and metoestrus, but began to increase after 10.00 hours on the 1st day of dioestrus, reaching a peak by 05.00 hours on the day of pro-oestrus and decreasing by 23.00 hours on the same day. Thus, it seems clear that the stimulation of $\left[{ }^{3} \mathrm{H}\right]$ leucine uptake into uterine protein between metoestrus and dioestrus cannot be due solely to oestrogen released during the same cycle. This applies more strongly to changes in early pregnancy and pseudopregnancy, the ovarian oestrogen secretion rate and plasma levels being hardly detectable during the first 2 days of pregnancy and then showing a small peak on Day 3 and a major peak on Day 4 at 15.00 hours, corresponding to the release of oestrogen for implantation on Day 5 (Shelesnyak, Kraicer \& Zielmaker, 1963; Psychoyos, 1967). The maximum levels scarcely reached those found during oestrus and metoestrus in the normal cycle. Since protein synthesis on Day 5 of pseudopregnancy, following the period of maximal oestrogen release, was no higher than on Day 1 or 2 , the increased protein synthesis on Days 3 and 4 cannot be ascribed solely to oestrogen release and other factors must be sought. Of these, interaction with progesterone may play a part.

Progesterone is secreted at measurable levels throughout the oestrous cycle and is increased in both pregnancy and pseudopregnancy (Hashimoto, Henricks, Anderson \& Melampy, 1968). Variations in the ratio and timing of doses of progesterone and oestrogen have been shown to have marked effects upon RNA metabolism in the uterus of the ovariectomized mouse (Miller \& Emmens, 1969), and it may be suggested that changes in the oestrogen : progesterone ratios during the oestrous cycle and during early pregnancy and pseudopregnancy are the primary causes of the major changes in protein synthesis. It should be noted that although Marcus \& Shelesnyak (1967) and Finn \& Martin (1970) have suggested that oestrogen secreted at pro-oestrus is associated with the formation of endometrial components essential to decidualization in the rat and mouse, there is as yet little data to support or deny this hypothesis. Additional study is needed before the similarities between gross protein synthesis of the uterus during the oestrous cycle and early pregnancy and pseudopregnancy can be ascribed to a common cause.

\section{ACKNOWLEDGMENTS}

Our thanks are due to the SRG for a CAPS award to R. J. Reid, and to ICI Ltd, Pharmaceuticals Division for a gift of ICI 46,474. 


\section{REFERENCES}

Bailey, J. L. (1967) Techniques in protein chemistry, 2nd edn, p. 346. Elsevier, Amsterdam.

ChristiE, G. A. (1966) Implantation of the rat embryo: glycogen and alkaline phosphatases. J. Reprod. Fert. 12, 279.

DeFeo, V. J. (1967) Decidualisation. In: Cellular Biology of the Uterus, p. 191. Ed. R. M. Wynne. North Holland Publishing Company, Amsterdam.

Finn, C. A. \& MARTIN, L. (1970) The role of the oestrogen secreted before oestrus in the preparation of the uterus for implantation in the mouse. F. Endocr. 47, 431.

HARPER, M.J. K. \& WALPOLE, A. L. (1967a) A new derivative of triphenylethylene effect on implantation and mode of action in rats. F. Reprod. Fert. 13, 101.

Harper, M. J. K. \& Walpole, A. L. (1967b) Mode of action of ICI 46,474 in preventing implantation in rats. J. Endocr. 37, 83.

Hashimoto, I., Henricks, D. M., Anderson, L. L. \& Melampy, R. M. (1968) Progesterone and pregn4-en-20 $\alpha$-ol-3-one in ovarian venous blood during various reproductive states in the rat. Endocrinology, 82, 333.

Heald, P. J. \& O'Grady, J. E. (1970) The uptake of $\left[{ }^{3} \mathrm{H}\right]$ uridine into the nucleic acids of rat uterus during early pregnancy. Biochem. F. 117, 65.

Heald, P. J., O'Grady, J. E, \& Howte, A. J. (1970) Quantitative changes in uterine nucleic acids during the oestrous cycle in rats. 7 . Reprod. Fert. $21,481$.

KREHBIEL, R. H. (1937) Cytological studies on the decidual reaction in the rat during early pregnancy and in the production of deciduomata. Physiol. Zool. 10, 212.

Marcus, G. \& Shelesnyak, M. C. (1967) Pro-oestrus oestrogen as a hormonal parameter of nidation. Endocrinology, 80, 1038.

MAYER, G. (1963) The experimental control of ovum implantation. In: Techniques in Endocrine Research, p. 245. Eds. P. Eckstein and F. Knowles. Academic Press, London.

Miller, B. G. \& Emmens, C. W. (1969) The effects of oestradiol and progesterone on the incorporation of tritiated uridine into the genital tract of the mouse. F. Endocr. 43, 247.

O'Grady, J. E., Heald, P. J. \& O'HaRz, A. (1970) Incorporation of $\left.{ }^{3}{ }^{3} \mathrm{H}\right]$ uridine into the ribonucleic acid of rat uterus during pseudopregnancy and in the presence of ICI 46,474 (trans-1- $(p-\beta$ dimethylaminoethoxyphenyl)-1,2 diphenylbut-I -ene). Biochem. F. 119,609.

Psychoyos, A. (1967) The hormonal interplay controlling egg-implantation in the rat. In: Advances in Reproductive Physiology, Vol. 2, p. 257. Ed. A. McLaren. Logos Press, London.

Reid, R. J. \& Heald, P. J. (1970) Uptake of [ $\left.{ }^{3} \mathrm{H}\right]$ leucine into proteins of rat uterus during early pregnancy. Biochim. biophys. Acta, 204, 278.

Shelesnyak, M. C., Kraicer, P. F. \& Zeilmaker, G. H. (1963) The oestrogen surge of pseudopregnancy and progravidity and its role in the process of decidualization. Acta endocr., Copenh. 42, 225.

SNedecor, G. W. \& Cochrane, W. G. (1967) Statistical methods, 6th edn. Iowa State University Press, Ames, Iowa.

Surani, M. A. H. \& Heald, P. J. (1971) The metabolism of glucose by rat uterus tissue in early pregnancy. Acta endocr., Copenh. 66, 16.

Yoshinaga, K., Hawkins, R. A. \& Stocker, J. F. (1969) Estrogen secretion by the rat ovary in vivo during the estrous cycle and pregnancy. Endocrinology, 85, 103. 